\title{
Wpływ dodatku superplastyfikatora na zwiększenie efektywności uszczelniania kolumn rur okładzinowych
}

\begin{abstract}
W artykule zaprezentowano możliwość zwiększenia efektywności uszczelniania kolumn rur okładzinowych wskutek obniżenia parametrów reologicznych zaczynów cementowych. Zamierzony efekt został osiągnięty za pomocą obecnie stosowanych dodatków upłynniających oraz innowacyjnych superplastyfikatorów. Bazowe próbki zaczynów cementowych poddano działaniu dodatków upłynniających, w celu określenia zdolności dyspergujących, a także zwiększenia efektywności wypełnienia przestrzeni pierścieniowej. Jako zaczyn bazowy zastosowano recepturę powszechnie stosowaną w warunkach otworowych.
\end{abstract}

Słowa kluczowe: plastyfikator, superplastyfikator, efektywność uszczelniania, parametry reologiczne.

\section{The effect of the addition of superplasticizer to increase the effectiveness of sealing casing}

This publication presents the possibility of increasing the effectiveness of sealing casings as a result of reducing the rheological parameters of cement slurries. The intended effect is achieved with the currently used plastificators and innovative superplastificators. The samples of cement slurry were treated by fluidifying additives in order to determine the dispersants ability and to increase the efficiency of filling the annular space. As base cement slurry, a formula commonly applied in borehole conditions was used.

Key words: plastificator, superplastificator, effectiveness of sealing, rheological parameters.

\section{Wprowadzenie}

Jednym z ważniejszych warunków pozwalających skutecznie wykonać zabieg cementowania rur okładzinowych jest odpowiedni dobór parametrów reologicznych zaczynu cementowego. Działanie takie jest niezbędne w celu uzyskania możliwie maksymalnego wyparcia płuczki z przestrzeni pierścieniowej w trakcie zabiegu cementowania. Warunek ten można spełnić, zapewniając określoną prędkość przepływu $\mathrm{w}$ trakcie tłoczenia zaczynu, a to z kolei wiąże się z potrzebą regulowania jego parametrów reologicznych za pomocą specjalnego rodzaju polimerów, nazywanych ogólnie upłynniaczami bądź też plastyfikatorami [4, 9, 10, 13].

Nie należy jednak mylić dwóch pojęć: plastyfikator i superplastyfikator. Różnica pomiędzy tymi środkami polega na tym, że podczas zastosowania dodatku plastyfikatora następuje częściowe zobojętnienie ładunków elektrycznych na powierzchni ziaren cementu. Wynikiem powyższego jest zwiększenie ruchliwości ziaren i - tym samym - płynności zaczynu [11]. Dodatek plastyfikatora pozwala na obniżenie ilości wody zarobowej do około 15\%, przy zachowaniu tej samej konsystencji zaczynu. Natomiast w przypadku drugiego rodzaju środków umożliwiających regulowanie parametrów reologicznych, reprezentowanych przez grupę superplastyfikatorów, działanie dyspersyjne polega na zmianie sił tarcia wewnętrznego cząsteczek zaczynu. Jest ono możliwe wskutek efektu sterycznego bądź elektrostatycznego, polegającego na odpychaniu zjonizowanych grup sulfonowych. Superplastyfikatory to polimery o mocno rozwiniętej budowie wewnętrznej. Charakteryzują się one zdolnością obniżania ilości wody zarobowej o ponad 15\% (niekiedy nawet do 40\%) przy zachowaniu tej samej konsystencji zaczynu $[3,8,11,15]$. 
Działanie dodatków upłynniających umożliwia uzyskanie turbulentnego przepływu zaczynu przy niższych wydajnościach pomp, co przekłada się na lepsze usunięcie płuczki z wypełnianej przestrzeni pierścieniowej, przy jednocześnie obniżonym ryzyku rozszczelinowania złoża $[6,16]$. W związku z powyższym na efektywność uszczelniania kolumn rur okładzinowych istotny wpływ ma działanie superplastyfikatora. Zagadnienie to zostanie omówione w dalszej części artykułu.

W celu określenia reologii zaczynów cementowych używa się głównie wiskozymetru obrotowego (fotografia 1). Określenie parametrów reologicznych zaczynu to podstawowe, a zarazem najważniejsze badanie, dające informacje o lepkości plastycznej, granicy płynięcia oraz wskaźniku konsystencji stosowanej cieczy wiertniczej. Na podstawie tego szybkiego badania możliwe jest już na etapie ,zarabiania" zaczynu cementowego modyfikowanie jego parametrów, wpływających na późniejszą sprawność i efektywność uszczelniania przestrzeni pierścieniowej.

W związku z powyższym w Laboratorium Zaczynów Uszczelniających Zakładu Technologii Wiercenia INiG - PIB, jak również podczas prac serwisowych na otworze wiertniczym, prowadzone są, między innymi, badania parame-

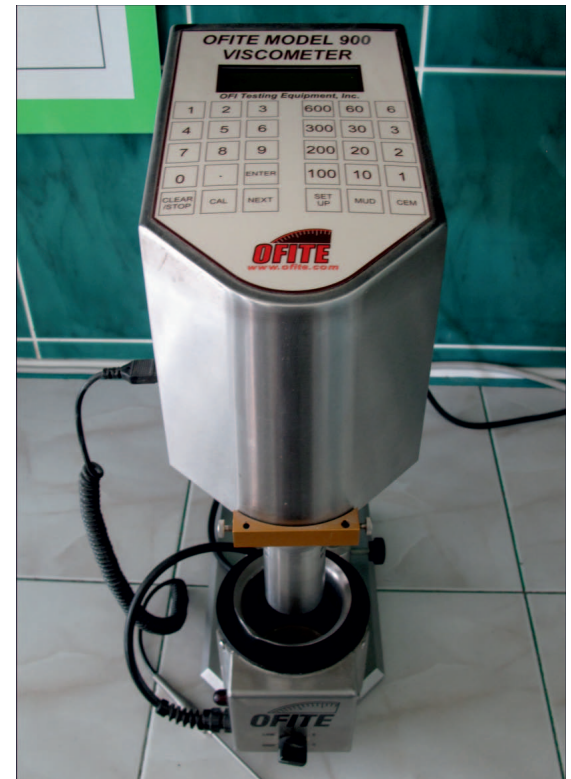

Fot. 1. Wiskozymetr obrotowy Ofite 900

trów reologicznych stosowanych cieczy wiertniczych. Prace te mają na celu opracowanie oraz modyfikację zaczynów uszczelniających (laboratorium INiG - PIB), a także działanie informacyjne i kontrolno-pomiarowe parametrów zaczy$\mathrm{nu}$ (prace serwisowe na otworze w warunkach polowych).

\section{Zaczyn cementowy jako ciecz nienewtonowska}

Pojęcie reologii zaczynów cementowych jest niezwykle istotne podczas projektowania składu zaczynu oraz w trakcie prowadzenia zabiegu cementowania. Właściwości reologiczne zaczynów cementowych dobierane są w sposób umożliwiający zoptymalizowanie procesu uszczelniania rur okładzinowych. Badania parametrów reologicznych zaczynu cementowego pozwalają wstępnie zweryfikować możliwości mieszania i tłoczenia zaczynu. Dodatkowo znajomość parametrów reologicznych umożliwia prawidłową ocenę rozkładu ciśnień słupa cementowego względem głębokości oraz określenie prędkości opadania zaczynu poza rurami. Istnieje również możliwość zaprojektowania wydatków tłoczenia zaczynu w celu osiągnięcia najlepszego usunięcia osadu płuczkowego ze ścian otworu.

Na podstawie badań stwierdzono, że zaczyny cementowe wykazują zgodność reologiczną z cieczami nienewtonowskimi. Są to układy o bardzo złożonych właściwościach opisywanych przez szereg modeli reologicznych, takich jak modele: Binghama, Oswalda de Waele'a, Cassona, Herschela-Bulkleya [5, 12, 14, 16]. Wpływ na przynależność do określonego modelu uzależniony jest między innymi od reakcji hydratacji zachodzących w spoiwie wiążącym w jednostce czasu. Podczas rozpatrywania wymiarów ziaren cementu zaczyny cementowe traktowane są jako układy dyspersyjne o strukturze zależnej od masowego ilorazu wody i suchego cementu oraz od wielkości uziarnienia cementu. Właściwości fizykochemiczne tworzącej się struktury zaczynu zależą od działających sił między ziarnami cementu i cząsteczkami wody $[2,15]$.

Podczas określania właściwości reologicznych świeżych zaczynów uszczelniających prowadzi się badania przy szerokich zakresach szybkości ścinania i naprężeń stycznych. Z punktu widzenia przydatności przemysłowej najczęściej przedstawianymi parametrami reologicznymi cieczy wiertniczych jest lepkość plastyczna i granica płynięcia $[5,7,12,16]$.

\section{Lepkość plastyczna zaczynu cementowego}

W celu uzyskania jak najlepszej efektywności uszczelniania kolumn rur okładzinowych należy wtłaczać zaczyn cementowy w uszczelnianą przestrzeń pierścieniową przy przepływie turbulentnym (wartość liczby Reynoldsa - nie mniej niż 3000) [5]. Aby uzyskać powyższy efekt, wymaga się stosowania sprzętu umożliwiającego wytworzenie dużych 
wydatków tłoczenia. Jednak takie działanie sprzyja niekiedy niekorzystnemu efektowi rozszczelinowania złoża. Dlatego też znacznie lepszym rozwiązaniem jest użycie dyspergatorów (upłynniaczy). Ich zastosowanie umożliwia obniżenie wartości lepkości plastycznej zaczynu. Dzięki temu istnieje możliwość tłoczenie zaczynu uszczelniającego przy mniejszym wydatku tłoczenia (mniejszej prędkości), co przyczynia się do zmniejszenia oporów przepływu. Zilustrowane zostało to na rysunku 1, gdzie widoczny jest wzrost oporów przepływu w zależności od lepkości plastycznej tłoczonego zaczynu cementowego $[1,5,10]$.

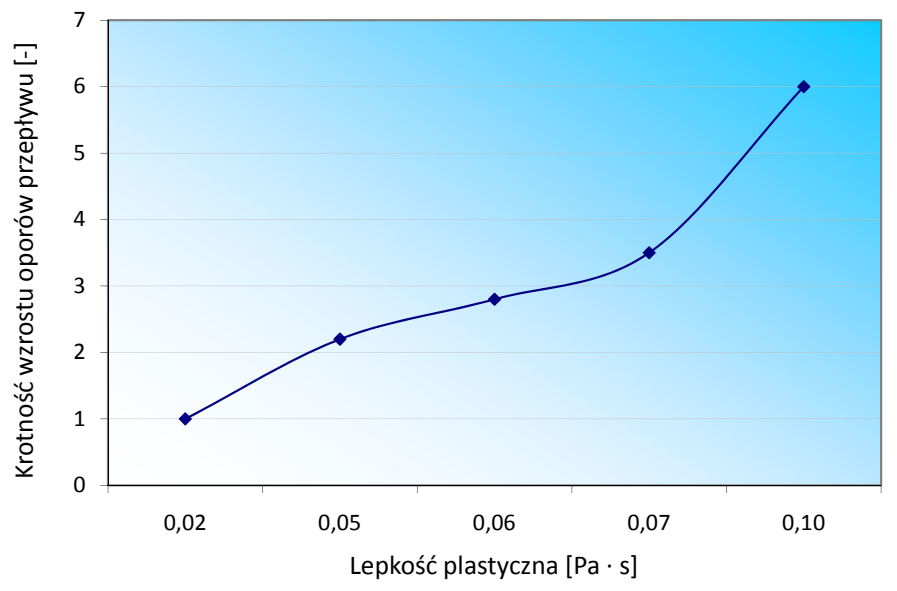

Rys. 1. Wzrost oporów przepływu w zależności od lepkości plastycznej zaczynu cementowego

\section{Granica płynięcia zaczynu cementowego}

Działanie środków dyspergujących jest korzystne ze względu na obniżenie zarówno wspomnianej lepkości plastycznej, jak również granicy płynięcia, która ma ważny wpływ na zwiększenie efektywności uszczelniania kolumn rur okładzinowych. Dzieje się tak z uwagi na to, że wysokie wartości granicy płynięcia w zaczynie cementowym powodują wzrost oporów przepływu, co w konsekwencji może doprowadzić do wystąpienia szczelinowania lub nawet ucieczki zaczynu cementowego w trakcie cementowania. Jeżeli przyjmiemy jako punkt odniesienia wartość granicy płynięcia na poziomie $6,2 \mathrm{~Pa}$, jak przedstawiono na rysunku 2, to wraz z jej wzrostem opór przepływu ulega kilkakrotnemu zwiększeniu. Zależność oporów przepływu jest oczywiście uwarunkowana wymaganym przepływem turbulentnym (liczba Re > 3000).

Analizując powyższe zachowania cieczy wiertniczych, stwierdzono, że regulacja parametrów reologicznych za pomocą środków dyspergujących ma znaczny wpływ na poprawę efektywności uszczelniania kolumn rur okładzinowych. Działanie środków dyspergujących - najogólniej mówiąc - polega na wcześniej wspomnianym pośrodkowaniu poziomów ładunków na powierzchniach poszczególnych

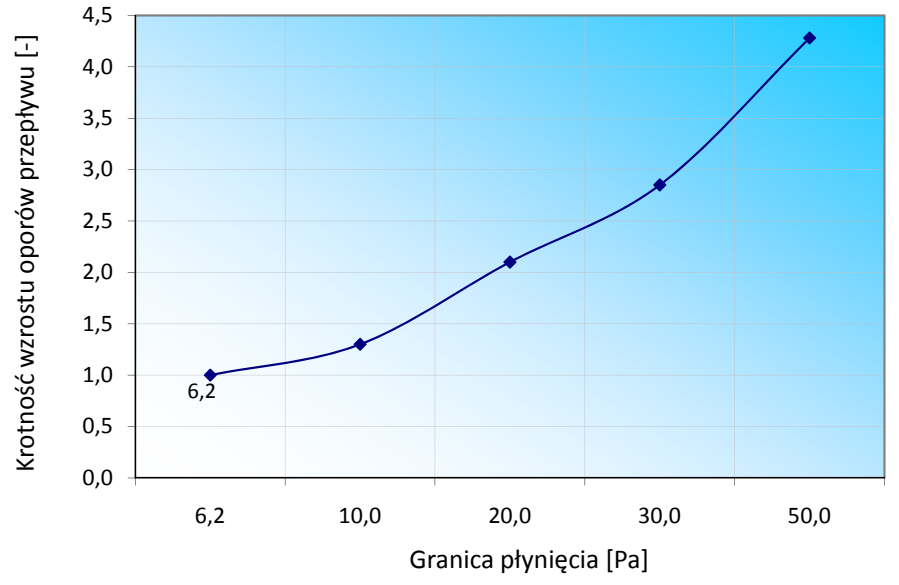

Rys. 2. Wzrost oporów przepływu w zależności od granicy płynięcia zaczynu cementowego

dodatków w zaczynie, co w efekcie pozwala na uzyskanie wymaganych wartości parametrów reologicznych zaczynu cementowego. Dzieje się tak, ponieważ środki dyspergujące pozwalają w pewnym sensie ,zaniechać” wzajemnego przyciągania ziaren pozostających $\mathrm{w}$ interakcji przeciwnych ładunków powierzchniowych powstałych podczas hydrolizy fazy CSH. [5-9].

\section{Przebieg prac badawczych}

Badania mające na celu dokonanie analizy możliwości poprawy efektywności uszczelniania kolumn rur okładzinowych, poprzez zastosowanie nowych dodatków do zaczynów cementowych, były wykonywane w Laboratorium Zaczynów Uszczelniających INiG - PIB, w oparciu o normy: PN-85/G-02320 Cementy i zaczyny cementowe do cementowania w otworach wiertniczych; PN-EN 10426-2 Przemyst naftowy i gazowniczy. Cementy i materialy do cementowania otworów.
Część 2: Badania cementów wiertniczych oraz API SPEC 10 Specification for materials and testing for well cements.

Zaprezentowany w niniejszej publikacji cykl badawczy polegał na wykazaniu działania różnego rodzaju dodatków upłynniających oraz ich wpływu na poprawę efektywności uszczelniania kolumn rur poprzez działanie upłynniające bądź uplastyczniające. Porównane zostały receptury dla warunków otworowych o temperaturze $50^{\circ} \mathrm{C}$ i ciśnieniu 
$15 \mathrm{MPa}$ (sporządzone przy użyciu cementu portlandzkiego klasy CEM I 32,5R) oraz dla warunków o temperaturze $75^{\circ} \mathrm{C}$ i ciśnieniu $35 \mathrm{MPa}$ (sporządzone przy użyciu cementu wiertniczego klasy G HSR). Porównanie takie miało na celu zobrazowanie działania środków w zależności od użytego spoiwa cementowego.

Badania parametrów reologicznych oparte zostały na określeniu modelu reologicznego zaczynów uszczelniających, czyli dopasowaniu krzywej reologicznej, która najlepiej opisywała wyniki pomiarów w układzie współrzędnych: naprężenia styczne $(\tau)$ - szybkość ścinania $(\gamma)[8,12]$. Obliczenia wykonano za pomocą modelu matematycznego dopasowanego do krzywych płynięcia cieczy wiertniczych.

Do badań wytypowany został zaczyn bazowy (dotychczas stosowany w warunkach otworowych). Następnie recepturę tę poddano modyfikacji, która polegała na zastąpieniu dodatku dyspergującego innowacyjnym dodatkiem superplastyfikatora w tej samej ilości co w zaczynie bazowym. Receptury zaczynów oraz ilościowe zawartości poszczególnych dodatków i domieszek zestawiono w tablicach 1 i 2, natomiast w tablicach 3 oraz 4 przedstawiono uzyskane wyniki para- metrów decydujących o efektywności uszczelniania, a także parametry reologiczne zaczynów.

Pierwsza grupa receptur reprezentowana jest przez składy przeznaczone do uszczelniania kolumn rur okładzinowych, posadowionych na głębokościach od około 800 do $1300 \mathrm{~m}$, uszczelnianych w temperaturze $50^{\circ} \mathrm{C}$ i przy ciśnieniu $15 \mathrm{MPa}$. Zaczyny dla tej grupy sporządzono na bazie cementu portlandzkiego klasy CEM I 32,5R. Analizując uzyskane wyniki, stwierdzono, że wszystkie receptury posiadają jednakową gęstość (rysunek 3). Widoczny jest wzrost rozlewności zaczynu w stosunku do receptury bazowej po wprowadzeniu dodatku superplastyfikatorów L1, L2 oraz L3. Dodatek L1 i L3 powoduje największy wzrost rozlewności, co wstępnie informuje o najskuteczniejszym działaniu dyspergującym (rysunek 3). Odstój wody, zarówno w zaczynie bazowym, jak i w zaczynach z dodatkiem superplastyfikatorów L1 i L2, jest na porównywalnym poziomie, jednak dyspergator L3, który wcześniej wykazywał najmocniejsze działanie upłynniające, spowodował wyeliminowanie wody wolnej (rysunek 3). Filtracja zaczynów z dodatkiem superplastyfikatorów L1 i L2 uległa znacznemu obniżeniu w porównaniu do zaczynu

Tablica 1. Receptury zaczynów cementowych dla warunków otworowych: temp. $50^{\circ} \mathrm{C}$, ciśn. $15 \mathrm{MPa}$ (składniki stałe) cement CEM I 32,5R = 100\%

\begin{tabular}{|c|c|c|c|c|c|c|c|c|c|c|}
\hline $\begin{array}{l}\text { Skład (nr) } \\
\text { współczyn- } \\
\text { nik (w/c) }\end{array}$ & $\begin{array}{c}\text { Dodatek } \\
\text { odpienia- } \\
\text { jący }\end{array}$ & $\begin{array}{l}\text { Dodatek } \\
\text { antyfiltra- } \\
\text { cyjny }\end{array}$ & $\begin{array}{l}\text { Dodatek } \\
\text { upłynnia- } \\
\text { jący (ba- } \\
\text { zowy) }\end{array}$ & $\begin{array}{l}\text { Dodatek } \\
\text { upłynnia- } \\
\text { jący L1 }\end{array}$ & $\begin{array}{l}\text { Dodatek } \\
\text { upłynnia- } \\
\text { jący L2 }\end{array}$ & $\begin{array}{l}\text { Dodatek } \\
\text { upłynnia- } \\
\text { jący L3 }\end{array}$ & Lateks & $\begin{array}{c}\text { Stabilizator } \\
\text { lateksu }\end{array}$ & $\begin{array}{c}\text { Dodatek } \\
\text { przyśpie- } \\
\text { szający }\end{array}$ & Mikrocement \\
\hline $\begin{array}{c}\mathrm{Nr} 1 \\
\mathrm{w} / \mathrm{c}=0,52\end{array}$ & 1,0 & 0,2 & 0,1 & - & - & - & 10,0 & 2,0 & 1,5 & 20,0 \\
\hline $\begin{array}{c}\mathrm{Nr} 2 \\
\mathrm{w} / \mathrm{c}=0,52\end{array}$ & 1,0 & 0,2 & - & 0,1 & - & - & 10,0 & 2,0 & 1,5 & 20,0 \\
\hline $\begin{array}{c}\mathrm{Nr} 3 \\
\mathrm{w} / \mathrm{c}=0,52\end{array}$ & 1,0 & 0,2 & - & - & 0,1 & - & 10,0 & 2,0 & 1,5 & 20,0 \\
\hline $\begin{array}{c}\mathrm{Nr} 4 \\
\mathrm{w} / \mathrm{c}=0,52\end{array}$ & 1,0 & 0,2 & - & - & - & 0,1 & 10,0 & 2,0 & 1,5 & 20,0 \\
\hline
\end{tabular}

Tablica 2. Receptury zaczynów cementowych dla warunków otworowych: temp. $75^{\circ} \mathrm{C}$, ciśn. $35 \mathrm{MPa}$ (składniki stałe) cement wiertniczy G HSR = 100\%

\begin{tabular}{|c|c|c|c|c|c|c|c|c|c|c|}
\hline $\begin{array}{c}\text { Skład (nr) } \\
\text { współczyn- } \\
\text { nik (w/c) }\end{array}$ & $\begin{array}{c}\text { Dodatek } \\
\text { odpienia- } \\
\text { jący }\end{array}$ & $\begin{array}{c}\text { Dodatek } \\
\text { antyfiltra- } \\
\text { cyjny }\end{array}$ & $\begin{array}{l}\text { Dodatek } \\
\text { uplynnia- } \\
\text { jący (ba- } \\
\text { zowy) }\end{array}$ & $\begin{array}{l}\text { Dodatek } \\
\text { upłynnia- } \\
\text { jący L1 }\end{array}$ & $\begin{array}{l}\text { Dodatek } \\
\text { upłynnia- } \\
\text { jący L2 }\end{array}$ & $\begin{array}{l}\text { Dodatek } \\
\text { upłynnia- } \\
\text { jący L3 }\end{array}$ & Lateks & $\begin{array}{c}\text { Stabilizator } \\
\text { lateksu }\end{array}$ & Mikrocement & $\begin{array}{c}\text { Dodatek } \\
\text { spęcznia- } \\
\text { jący }\end{array}$ \\
\hline $\begin{array}{c}\mathrm{Nr} 5 \\
\mathrm{w} / \mathrm{c}=0,52\end{array}$ & 0,5 & 0,2 & 0,25 & - & - & - & 10,0 & 2,0 & 20,0 & 0,30 \\
\hline $\begin{array}{c}\mathrm{Nr} 6 \\
\mathrm{w} / \mathrm{c}=0,52\end{array}$ & 0,5 & 0,2 & - & 0,25 & - & - & 10,0 & 2,0 & 20,0 & 0,30 \\
\hline $\begin{array}{c}\mathrm{Nr} 7 \\
\mathrm{w} / \mathrm{c}=0,52\end{array}$ & 0,5 & 0,2 & - & - & 0,25 & - & 10,0 & 2,0 & 20,0 & 0,30 \\
\hline $\begin{array}{c}\mathrm{Nr} 8 \\
\mathrm{w} / \mathrm{c}=0,52\end{array}$ & 0,5 & 0,2 & - & - & - & 0,25 & 10,0 & 2,0 & 20,0 & 0,30 \\
\hline
\end{tabular}


Tablica 3. Parametry decydujące o efektywności uszczelniania zaczynów cementowych

\begin{tabular}{|c|c|c|c|c|c|c|c|c|c|c|c|c|c|c|}
\hline \multirow{2}{*}{ 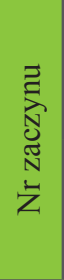 } & \multirow{2}{*}{ 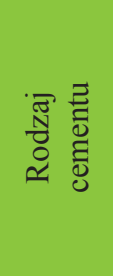 } & \multirow{2}{*}{$\begin{array}{c}\text { Temperatura } \\
{\left[{ }^{\circ} \mathrm{C}\right]}\end{array}$} & \multirow{2}{*}{ 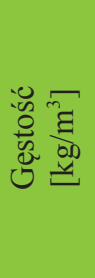 } & \multirow{2}{*}{ 惫 } & \multirow{2}{*}{$\begin{array}{l}\frac{\lambda}{8} \\
\vdots \\
\vdots 0 \\
0 \\
\frac{0}{0} \\
0 \\
0\end{array}$} & \multirow{2}{*}{$\begin{array}{l}\text { Filtracja } \\
\begin{array}{c}{\left[\mathrm{cm}^{3} /\right.} \\
30 \mathrm{~min}]\end{array}\end{array}$} & \multicolumn{2}{|c|}{$\begin{array}{c}\text { Czas gęstnienia* } \\
\text { [godz.:min] } \\
\text { Czas dojścia }^{*}\end{array}$} & \multicolumn{6}{|c|}{$\begin{array}{c}\text { Odczyty z aparatu Fann } \\
\text { [obr./min] }\end{array}$} \\
\hline & & & & & & & $30 \mathrm{Bc}$ & $100 \mathrm{Bc}$ & 600 & 300 & 200 & 100 & 6 & 3 \\
\hline 1 & \multirow{4}{*}{$\begin{array}{l}\text { Cement } \\
\text { CEM I } \\
32,5 \mathrm{R}\end{array}$} & \multirow{4}{*}{$\begin{array}{c}50^{\circ} \mathrm{C} \\
15 \mathrm{MPa}\end{array}$} & 1790 & 225 & 0,9 & 42,0 & $1: 12$ & $1: 38$ & 220 & 190 & 140 & 92 & 15,0 & 8,0 \\
\hline 2 & & & 1790 & 310 & 0,5 & 17,0 & $1: 21$ & $1: 49$ & 184 & 98 & 67 & 36 & 6,0 & 4,0 \\
\hline 3 & & & 1790 & 270 & 0,9 & 17,0 & $1: 42$ & $2: 17$ & 176 & 92 & 64 & 34 & 5,0 & 3,0 \\
\hline 4 & & & 1790 & 310 & 0,0 & 34,0 & $1: 40$ & $1: 58$ & 153 & 80 & 56 & 30 & 4,0 & 3,0 \\
\hline 5 & \multirow{4}{*}{$\begin{array}{l}\text { Cement } \\
\text { G HSR }\end{array}$} & \multirow{4}{*}{$\begin{array}{c}75^{\circ} \mathrm{C} \\
35 \mathrm{MPa}\end{array}$} & 1800 & 240 & 2,0 & 8,4 & $4: 13$ & $4: 40$ & 250 & 215 & 165 & 120 & 30,0 & 12,0 \\
\hline 6 & & & 1800 & 290 & 3,0 & 19,0 & 4:00 & $4: 19$ & 78 & 38 & 23 & 13 & 2,5 & 0,3 \\
\hline 7 & & & 1800 & 290 & 4,0 & 26,0 & $4: 31$ & $4: 52$ & 74 & 34 & 19 & 10 & 1,5 & 0,2 \\
\hline 8 & & & 1800 & 320 & 0,2 & 45,0 & $2: 35$ & $2: 53$ & 66 & 31 & 16 & 7 & 1,0 & 0,1 \\
\hline
\end{tabular}

* Czas dojścia do temp: $50^{\circ} \mathrm{C}=30 \mathrm{~min}$.; do temp. $75^{\circ} \mathrm{C}=70 \mathrm{~min}$.

Tablica 4. Parametry reologiczne zaczynów cementowych

\begin{tabular}{|c|c|c|c|c|c|c|c|c|c|}
\hline \multirow{2}{*}{$\begin{array}{l}\text { Model } \\
\text { reologiczny }\end{array}$} & \multirow{2}{*}{ Parametry reologiczne } & \multicolumn{8}{|c|}{ Nr zaczynu } \\
\hline & & 1 & 2 & 3 & 4 & 5 & 6 & 7 & 8 \\
\hline \multirow{3}{*}{ Model Binghama } & Lepkość plastyczna $[\mathrm{Pa} \cdot \mathrm{s}]$ & 0,1080 & 0,0904 & 0,876 & 0,0753 & 0,1171 & 0,0385 & 0,0368 & 0,0332 \\
\hline & Granica płynięcia $[\mathrm{Pa}]$ & 19,5674 & 2,6200 & 2,1073 & 1,9279 & 27,2470 & 0,0363 & 0,8203 & 1,0918 \\
\hline & $\begin{array}{l}\text { Współczynnik } \\
\text { korelacji [-] }\end{array}$ & 0,9214 & 0,9996 & 0,9997 & 0,9996 & 0,9135 & 0,9987 & 0,9963 & 0,9949 \\
\hline \multirow{3}{*}{$\begin{array}{l}\text { Model Ostwalda de } \\
\text { Waele'a }\end{array}$} & $\begin{array}{l}\text { Współczynnik } \\
\text { konsystencji }\left[\mathrm{Pa} \cdot \mathrm{s}^{\mathrm{n}}\right]\end{array}$ & 1,6097 & 0,5950 & 0,4339 & 0,3988 & 3,2580 & 0,0671 & 0,0364 & 0,0171 \\
\hline & Wykładnik potęgowy [-] & 0,6410 & 0,7068 & 0,7500 & 0,7409 & 0,5538 & 0,9109 & 0,9868 & 1,0835 \\
\hline & $\begin{array}{l}\text { Współczynnik } \\
\text { korelacji [-] }\end{array}$ & 0,9647 & 0,9810 & 0,9865 & 0,9857 & 0,9733 & 0,9943 & 0,9908 & 0,9935 \\
\hline \multirow{3}{*}{ Model Cassona } & Lepkość Cassona $[\mathrm{Pa} \cdot \mathrm{s}]$ & 0,0928 & 0,0768 & 0,0759 & 0,0657 & 0,0898 & 0,0353 & 0,0348 & 0,0326 \\
\hline & Granica płynięcia $[\mathrm{Pa}]$ & 4,4633 & 0,6218 & 0,4096 & 0,3803 & 8,7546 & 0,0310 & 0,0010 & 0,0311 \\
\hline & $\begin{array}{l}\text { Współczynnik } \\
\text { korelacji [-] }\end{array}$ & 0,9343 & 0,9998 & 0,9999 & 0,9999 & 0,9368 & 0,9974 & 0,9948 & 0,9796 \\
\hline \multirow{4}{*}{$\begin{array}{l}\text { Model Herschela- } \\
\text { Bulkleya }\end{array}$} & Granica płynięcia $[\mathrm{Pa}]$ & 16,7607 & 1,5751 & 1,1833 & 1,0502 & 23,3410 & 0,5652 & 0,3215 & 0,0071 \\
\hline & $\begin{array}{l}\text { Współczynnik } \\
\text { konsystencji }\left[\mathrm{Pa} \cdot \mathrm{s}^{\mathrm{n}}\right]\end{array}$ & 10,6937 & 0,1341 & 0,1249 & 0,1120 & 18,1190 & 0,0210 & 0,0100 & 0,0082 \\
\hline & Wykładnik potęgowy [-] & 0,3643 & 0,9433 & 0,9475 & 0,9429 & 0,3092 & 1,0870 & 1,1812 & 1,2021 \\
\hline & $\begin{array}{l}\text { Współczynnik } \\
\text { korelacji [-] }\end{array}$ & 0,9922 & 1,0000 & 1,0000 & 1,0000 & 0,9955 & 0,9994 & 0,9994 & 0,9986 \\
\hline
\end{tabular}

*Wyróżnieniem zaznaczono model reologiczny o najwyższym współczynniku korelacji Pearsona.

bazowego. Najmniejszy spadek wartości filtracji odnotowano przy użyciu dodatku środka L3 (rysunek 3). Analizując czasy gęstnienia zaczynów poddanych modyfikacjom, zauważa się trend wzrostu zarówno początku, jak i końca czasu gęstnienia (rysunek 4). Takie zachowanie może być spowodowane obniżeniem wartości lepkości plastycznej zaczynów wskutek zastosowanych dodatków dyspergujących.

Najskuteczniejsze działanie superplastyfikatora L3 widoczne jest na wykresie (rysunek 5), gdzie parametry reologiczne, tj. granica płynięcia oraz współczynnik konsystencji, opisywane przez model Herschela-Bulkleya w tablicy 4, ulegają obniżeniu pod wpływem użytych dodatków. Dodatek superplastyfikatora L3 spowodował najwyraźniejsze obniżenie lepkości plastycznej opisywanej modelem Cassona. Takie działanie środka L3 było zauważalne we wstępnym badaniu płynności zaczynu (próba rozlewności). 


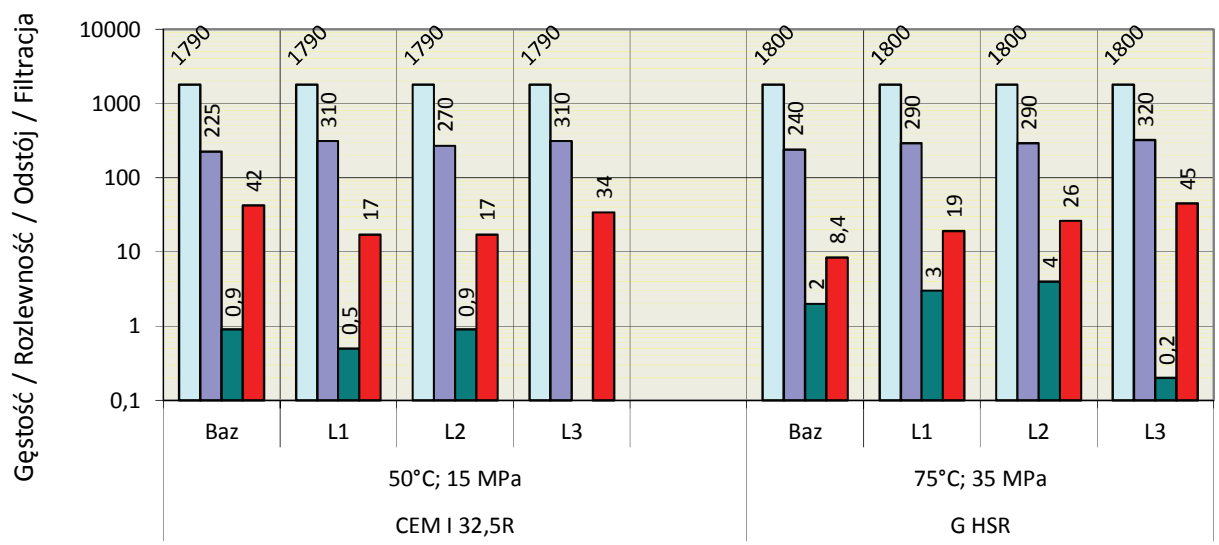

Nr zaczynu; warunki hydratacji; rodzaj spoiwa

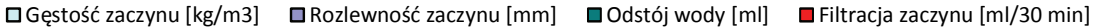

Rys. 3. Zestawienie wyników gęstości, rozlewności, odstoju oraz filtracji zaczynów cementowych

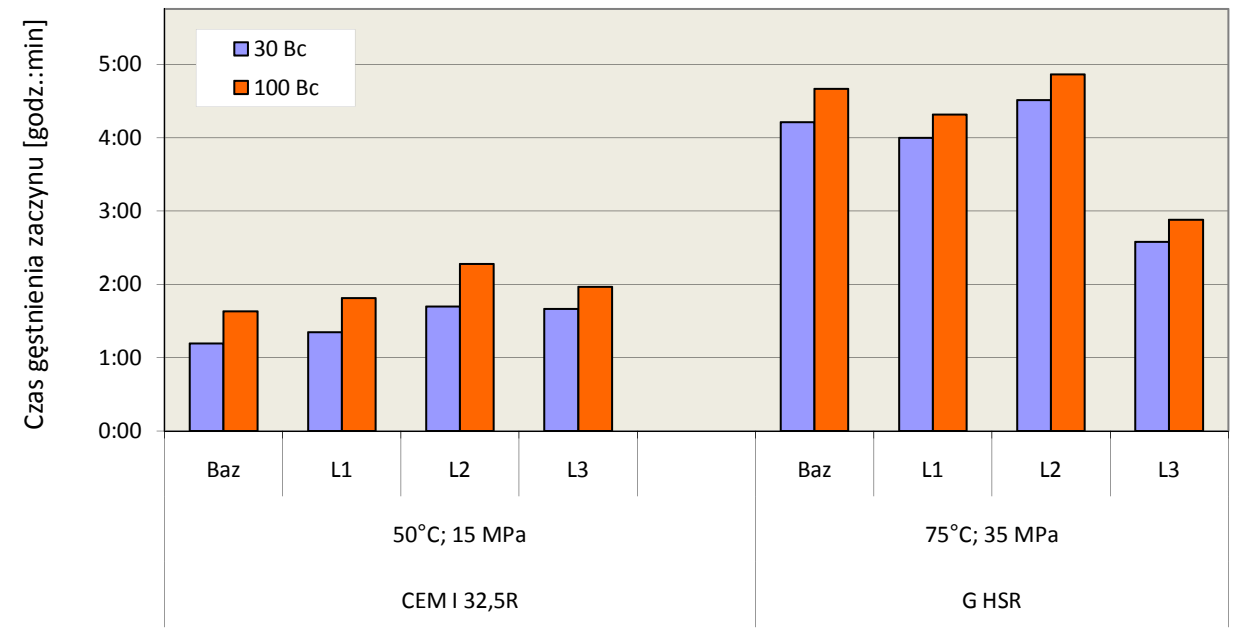

Nr zaczynu; warunki hydratacji; rodzaj spoiwa

Rys. 4. Zestawienie pomiarów czasu gęstnienia zaczynów cementowych

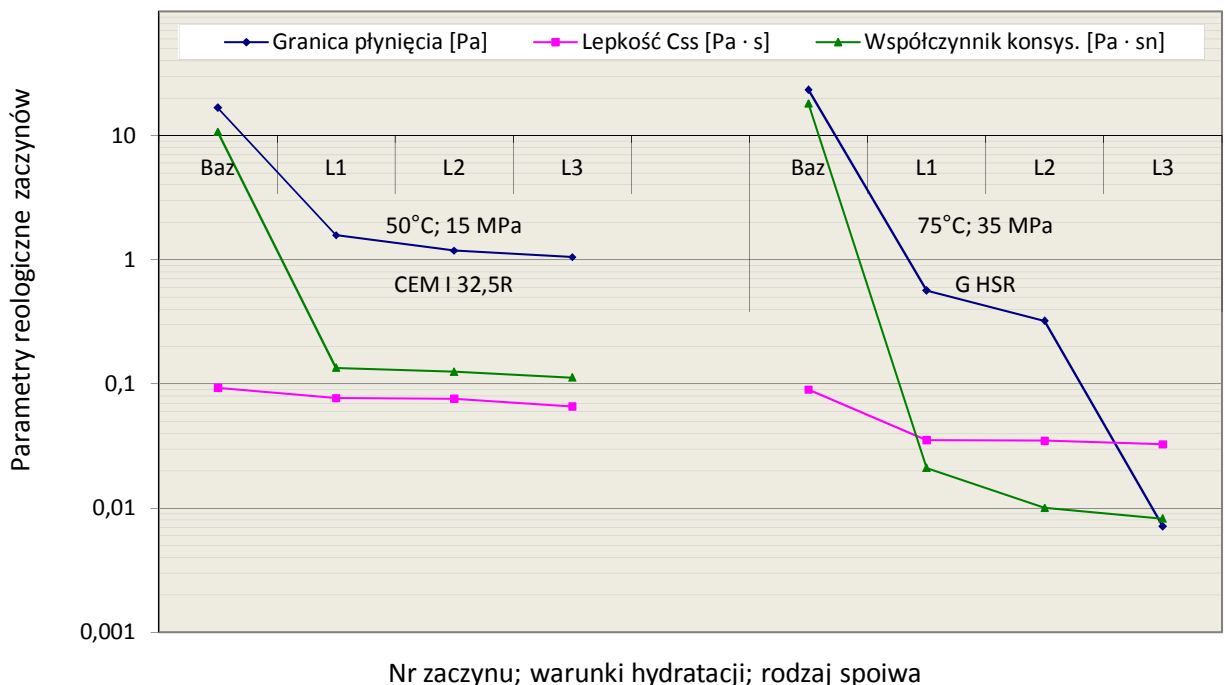

Rys. 5. Zestawienie wyników badań parametrów reologicznych zaczynów cementowych 
W drugiej grupie receptur znajdowały się składy przeznaczone do uszczelniania kolumn rur okładzinowych na głębokościach od około $1400 \mathrm{~m}$ do około $2000 \mathrm{~m}$ (temp. $75^{\circ} \mathrm{C}$, ciśn. $35 \mathrm{MPa}$ ). Spoiwem wiążącym w tej grupie zaczynów był cement wiertniczy klasy G HSR. Analizując uzyskane wyniki badań, również w tej grupie receptur, zauważa się niezmienne wartości gęstości zaczynów. Wstępne badanie płynności zaczynu (rozlewność) informuje, że zaczyn z dodatkiem superplastyfikatora L3 wykazuje najmocniejsze działanie dyspergujące (rysunek 3). Potwierdzeniem powyższego jest zestawienie parametrów reologicznych na rysunku 5, gdzie zaczyn z dodatkiem środka dyspergującego L3 posiada najmniejszą wartość lepkości plastycznej opisywanej przez model Cassona oraz najniższą wartość granicy płynięcia i współczynnik konsystencji przedstawiany przez model Herschela-Bulkleya w tablicy 4. Dodatek superplastyfikatora L3 obniżył wartość odstoju wody, jednak nieznacznie wzrosła filtracja zaczynu. Wzrost ten nie powoduje jednak przekroczenia dopuszczalnej wartości filtracji, zgodnie z projektem uszczelniania kolumn rur okładzinowych w danych warunkach otworowych.
Konkludując powyższe rozważanie, stwierdzono, że dodatek superplastyfikatora L3 wykazuje znacznie skuteczniejsze działanie dyspergujące niż środek upłynniający stosowany w zaczynie bazowym. Dodatek ten, oprócz najważniejszego działania, czyli poprawy parametrów reologicznych wpływających na dokładniejsze wypełnienie uszczelnianej przestrzeni pierścieniowej, wykazuje korzystny wpływ na pozostałe parametry decydujące o efektywności uszczelniania. Wyeliminowano lub znacznie obniżono wartość odstoju wody, uzyskano odpowiednie parametry filtracji zaczynu, a czas gęstnienia nie uległ znacznemu wydłużeniu. Takie działanie wspomnianych dodatków testowanych superplastyfikatorów ma istotny wpływ na zwiększenie efektywności uszczelniania kolumn rur okładzinowych. Ponadto nadmienić należy, że stosowanie dodatków superplastyfikatorów nowej generacji umożliwia znaczne obniżenie współczynnika wodno-cementowego przy zachowaniu tej samej konsystencji, wynikiem czego jest wyraźna poprawa parametrów mechanicznych stwardniałego zaczynu cementowego.

\section{Podsumowanie}

Na podstawie uzyskanych wyników badań wyciągnięto następujące wnioski:

1. Z uwagi na możliwość wystąpienia nieprzewidywalnych zachowań w działaniu innowacyjnych dodatków i domieszek do zaczynów uszczelniających, muszą być one bezwzględnie poddawane badaniom laboratoryjnym na specjalistycznej aparaturze.

2. Dodatek superplastyfikatora wpływa na zwiększenie efektywności uszczelniania kolumn rur okładzinowych. Jest to spowodowane dokładniejszym wypełnieniem cementowanej przestrzeni pierścieniowej, lepszym usunięciem pozostałości niewypłukanego osadu filtracyjnego oraz uzyskaniem turbulentnego przepływu cieczy podczas wypełniania przestrzeni pierścieniowej zaczynem cementowym.

3. Stosowanie dodatków superplastyfikatorów, pomimo korzystnego wpływu na parametry reologiczne zaczynu, może niekiedy powodować zwiększenie odstoju wody oraz filtracji zaczynu (głównie w zaczynach sporządzonych na bazie cementu wiertniczego klasy G HSR). Należy brać pod uwagę takie zachowanie projektowanego zaczynu i w związku z powyższym uwzględniać potrzebę zastosowania dodatkowych środków antyfiltracyjnych.

4. Ze względu na to, że środki upłynniające bardzo mocno obniżają współczynnik konsystencji, niekiedy może być niezbędne zastosowanie dodatku bentonitu, który pozwoli na wyeliminowanie niepożądanego zjawiska sedymentacji fazy stałej w wiążącym zaczynie.

5. Analizując czasy gęstnienia zaczynów poddanych modyfikacjom, zauważa się trend wydłużenia zarówno czasu początku, jak i końca gęstnienia (rysunek 4). Takie zachowanie może być spowodowane obniżeniem lepkości plastycznej zaczynów wskutek zastosowanych dodatków dyspergujących.

6. Zauważalne jest znacznie mocniejsze działanie dodatku superplastyfikatora w zaczynach sporządzonych na bazie cementu wiertniczego klasy G HSR (uzyskano niższe wartości lepkości plastycznej, wytrzymałości strukturalnej oraz granicy płynięcia). Może być to spowodowane większym rozmiarem cząstek cementu wiertniczego klasy G HSR, które są niejako „otaczane” przez cząsteczki superplastyfikatora.

7. Obniżenie wartości lepkości plastycznej zaczynu cementowego poprzez zastosowanie dodatku superplastyfikatora powoduje zwiększenie przetłaczalności, a tym samym obniżenie ciśnienia tłoczenia. Jest to istotne $\mathrm{z}$ uwagi na możliwość uzyskania przepływu turbulentnego, przy jednocześnie mniejszym prawdopodobieństwie wystąpienia rozszczelinowania strefy przyodwiertowej. 
Artykuł powstał na podstawie pracy badawczej pt. Analiza możliwości poprawy efektywności uszczelniania rur okładzinowych poprzez zastosowanie nowych dodatków do zaczynów cementowych - praca INiG - PIB na zlecenie MNiSW; nr archiwalny: DK-4100/35/15, nr zlecenia: 35/KW/15.

\section{Literatura}

[1] Dębińska E.: Wyznaczanie statycznej wytrzymałości strukturalnej $i$ wczesnej wytrzymałości mechanicznej zaczynów cementowych. Nafta-Gaz 2013, nr 2, s. 134-142.

[2] Kurdowski W.: Chemia cementu. Wydawnictwo Naukowe PWN. Warszawa 1991

[3] Małolepszy J., Wójcik J.: Wpływ dodatków chemicznych na procesy hydratacji genelitu. Cz. I. Cement-Wapno-Gips 1987, nr 6, s. 114-118.

[4] Nelson E. B. et al.: Well Cementing. Schlumberger Educational Service, Houston, Teksas, 1990.

[5] Rzeczpospolita tupkowa. Studium wiedzy o gazie z formacji tupkowych. Praca zbiorowa. Prace Naukowe INiG 2012, nr 183.

[6] Rzepka M., Stryczek S.: Laboratoryjne metody określania parametrów technologicznych świeżych zaczynów uszczelniajacych przed zabiegiem zwiazanym z procesem uszczelniania kolumn rur okładzinowych w otworach wiertniczych. Wiertnictwo, Nafta, Gaz 2008, nr 25/2, s. 625-636.

[7] Rzepka M.: Badania dtugookresowej odporności korozyjnej stwardniatych zaczynów cementowych stosowanych w wiertnictwie. Nafta-Gaz 2015, nr 7, s. 451-460.

[8] Stryczek S.: Wpływ superplastyfikatorów na właściwości reologiczne zaczynów cementowych. Nowoczesne Budownictwo Inżynieryjne 2011, s. 60-62.

[9] Stryczek S., Wiśniowski R., Gonet A., Ferens W.: Parametry reologiczne świeżych zaczynów uszczelniających $w$ zależności od czasu ich sporzadzania. Wiertnictwo, Nafta, Gaz 2009, nr 26/1-2, s. 369-382.

[10] Stryczek S., Wiśniowski R., Gonet A., Złotkowski A.: The influence of time of rheological parameters of fresh cement slurries. AGH Drilling, Oil, Gas 2014, vol. 31, nr 1, s. 123-133.
[11] Stryczek S., Wiśniowski R., Kumala B.: Wpływ superplastyfikatora na parametry technologiczne zaczynów uszczelniajacych sporzadzonych na osnowie cementów portlandzko-popiołowych. Wiertnictwo, Nafta, Gaz 2008, nr 25/2, s. 717-731.

[12] Wiśniowski R.: Metodyka określania modelu reologicznego cieczy wiertniczej. Rocznik AGH. Wiertnictwo, Nafta, Gaz 2001, nr 18/1, s. 247-261.

[13] Wiśniowski R.: O oporach przepływu cieczy wiertniczych. Wiertnictwo, Nafta, Gaz 2003, nr 20/2, s. 441-455.

[14] Wiśniowski R., Skrzypaszek K.: Analiza modeli reologicznych stosowanych $w$ technologiach inżynierskich. Wiertnictwo, Nafta, Gaz 2006, nr 23/1, s. 523-532.

[15] Wiśniowski R., Stryczek S., Skrzypaszek K.: Kierunki rozwoju badań nad reologia plynów wiertniczych. Wiertnictwo, Nafta, Gaz 2007, nr 24, s. 595-607.

[16] Wiśniowski R., Stryczek S., Skrzypaszek K.: Wyznaczanie oporów laminarnego przepływu zaczynów cementowych, opisywanych modelem Herschela-Bulkleya. Wiertnictwo, Nafta, Gaz 2006, nr 23/1, s. 533-542.

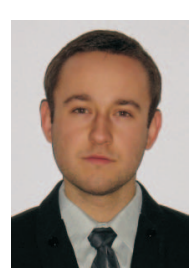

Dr inż. Marcin KREMIENIEWSKI

Adiunkt w Zakładzie Technologii Wiercenia.

Instytut Nafty i Gazu - Państwowy Instytut Badawczy

ul. Lubicz 25 A

31-503 Kraków

E-mail: marcin.kremieniewski@inig.pl 